Original Research Paper

\title{
Habitat Characteristic of The Long-Tail Monkeys (Macaca fascicularis) at Natural Tourism Park (NTP) Pengsong Mount, West Lombok
}

\author{
Ratu Mas Tara Indriani ${ }^{1}$, M. Yamin ${ }^{1 *}$, I Putu Artayasa ${ }^{1}$ \\ ${ }^{1}$ Program Studi Pendidikan Biologi FKIP Universitas Mataram, Indonesia
}

\author{
Article History \\ Received : June $20^{\text {th }}, 2021$ \\ Revised : July 19 $9^{\text {th }}, 2021$ \\ Accepted : August 21 ${ }^{\text {th }}, 2021$ \\ Published : September $13^{\text {th }}, 2021$ \\ *Corresponding Author: \\ M. Yamin, \\ Program Studi Pendidikan \\ Biologi FKIP Universitas \\ Mataram, Mataram, Indonesia; \\ Email: \\ muhammadyamin.fkip@gmail. \\ $\underline{\text { com }}$
}

\begin{abstract}
Pengsong Mount Natural Tourism Park (NTP) is a habitat for long-tailed monkeys (Macaca fascicularis) in West Lombok. This study aims to determine the habitat characteristics of Macaca fascicularis in Pengsong Mount Natural Tourism Park (NTP), West Lombok. The object of this research is the long-tailed monkey (Macaca fascicularis) and all vegetation observed in the habitat of this species. Habitat characteristic data was collected using the plot method placed on an observation transect. Vegetation data taken includes vegetation at the level of seedlings, saplings, poles, and trees. Data on the physical conditions of the habitats collected included air temperature, air humidity, soil moisture, and soil $\mathrm{pH}$. The data on the activity of the long-tailed monkeys studied were the daily activities of the monkeys in their habitat. The results showed that the habitat characteristics of long-tailed monkeys in Pengsong Mount Natural Tourism Park (NTP) is overgrown by 25 types of plants belonging to 15 families, has an average air temperature of $27.67^{\circ} \mathrm{C}$, an average air humidity of $65^{\circ} \mathrm{C}$, an average soil moisture of $55.67 \%$, and the average $\mathrm{pH}$ of 5.2. The value of plant diversity in the Pengsong Mount Natural Tourism Park (NTP) area is 2.623 so that the value of plant diversity is classified as moderate. The value of plant evenness in the Pengsong Mount Natural Tourism Park (NTP) area is 0.815 so that the value of plant evenness is high.
\end{abstract}

Keywords: Habitat Characteristics, Macaca fascicularis, Pengsong Mount Natural Tourism Park (NTP)

\section{Pendahuluan}

Habitat merupakan suatu kawasan berhutan maupun tidak berhutan yang menjadi tempat ditemukannya organisme tertentu. Setiap habitat satwa liar akan didukung oleh komponen biotik dan abiotik yang disesuaikan dengan kebutuhan satwa liar tersebut, seperti air, udara, iklim, vegetasi, mikro dan makrofauna juga manusia (Alikodra, 2002). Secara umum habitat monyet ekor panjang berada di kawasan hutan dataran rendah, dan di sekitar kawasan perumahan penduduk. Salah satu habitat dari monyet ekor panjang (Macaca fascicularis) adalah Taman Wisata Alam Gunung Pengsong (Yamin et al., 2021).

Gunung Pengsong merupakan kawasan hutan dataran rendah (Low Land Forest) sebab, hutan yang berada pada ketinggian $700 \mathrm{~m}$ di atas permukaan laut (Departemen Kehutanan, 1989). Kawasan Gunung Pengsong, memiliki beberapa tipe habitat, seperti hutan, semak, padang rumput, tegalan/kebun dan persawahan (Yamin et al., 2021). Monyet ekor panjang di TWA Gunung Pengsong memberikan rasa tidak nyaman terhadap pengunjung, mereka menciptakan kerusakan pada rumah warga, dan tanaman hasil pertanian (Jawadi \& Raden, 2018).

Monyet ekor panjang (Macaca fascicularis) merupakan salah satu jenis monyet yang memiliki panjang ekor kurang lebih sama dengan panjang tubuh berkisar antara 385-655 nm (Supriatna \& Rizki, 2016). Monyet ekor panjang merupakan satwa primata sosial, prilaku yang muncul saat interaksi sosial yakni social afiliaction, social agonism dan non-social 
activities. Perilaku tersebut di antaranya bergerak (berpindah tempat), grooming (menelisik), bermain, inaktif (istirahat), makan, agonistik (berkelahi), tidur, kawin, dan bersuara (Sari et al., 2014). Monyet ekor panjang cenderung menyukai jenis pohon untuk tidur yang memiliki tajuk yang luas dan terlindung, serta berada dekat dengan sumber air (Setiawan et al., 2013).

Saat ini monyet ekor panjang masuk dalam kategori "Least concern" karena paling sedikit diperhatikan (CITES, 2014). Di Asia Tenggara banyak Monyet Ekor Panjang (MEP) sinanthropik (satwa yang tinggal dengan dan mendapat manfaat dari manusia), dan hanya sedikit yang masih liar dan tidak terganggu oleh manusia. Tumpang tindih antara manusia dan MEP semakin meningkat karena hilangnya habitat (Gumert, 2011). Monyet ekor panjang dimanfaatkan untuk dijadikan makanan siap saji dan sering dimanfaatkan untuk keperluan penelitian medis, terutama penelitian vaksin polio, riset biomedik dan psikologis (Soehartono $\&$ Mardiastuti 2003).

Habitat MEP banyak yang mengalami kerusakan diakibatkan oleh adanya aktivitas masyarakat di sekitar hutan. Beberapa kegiatan masyarakat yang teridentifikasi yang berakibat pada habitat dan populasi MEP adalah perambahan hutan, penebangan pohon, dan kebakaran lahan (Afitah, 2016). Untuk mencegah kerusakan habitat dan kepunahan lebih lanjut maka sangat perlu untuk melaksanakan upaya konservasi (pemeliharaan dan perkembangbiakkan MEP). Upaya pelestarian hanya dapat berhasil bila didukung pengetahuan tentang kehidupan MEP dan habitatnya (Anita $e t$ al., 2015).

Habitat merupakan suatu hal mendasar yang harus diperhatikan dalam usaha kelestarian spesies terlebih lagi dengan adanya perubahan lingkungan yang cepat dan banyaknya kegiatan wisata di TWA Gunung Pengsong. Penelitian mengenai karakteristik habitat MEP belum pernah dilakukan sebelumnya di Taman Wisata Alam (TWA) Gunung Pengsong. Oleh karena itu, penelitian ini penting dilakukan. Penelitian ini diharapkan dapat memberikan informasi kepada pemerintah, peneliti, serta masyarakat mengenai karakteristik pada habitat MEP di TWA (Taman Wisata Alam) Gunung Pengsong dan dapat menjadi sumber ilmu untuk penelitian selanjutnya.

\section{Bahan dan Metode}

Jenis penelitian yang digunakan ialah deskriptif eksploratif. Penelitian dilakukan di Kawasan TWA Gunung Pengsong Lombok Barat. Kawasan TWA Gunung Pengsong memiliki luas wilayah 11 hektare. Penelitian ini dilakukan selama dua bulan dari bulan Februari sampai Maret 2021 pada saat musim hujan, dengan titik koordinat $-8^{\circ} 64.18631^{\prime}-116^{\circ}$ 08.74707'.

Subjek penelitian adalah MEP yang terdapat di dalam plot dan objek penelitian adalah karakteristik habitat MEP di TWA Gunung Pengsong Lombok Barat. Sampel penelitian ini adalah area yang ditempati oleh Macaca fascicularis di TWA Gunung Pengsong pada tiga titik stasiun. Populasi dalam penelitian ini adalah ekosistem di daerah yang ditempati oleh Macaca fascicularis di TWA Gunung Pengsong. Pengambilan sampel menggunakan teknik purposive sampling yang dilakukan pada tiga titik stasiun pengamatan (Gambar 1).

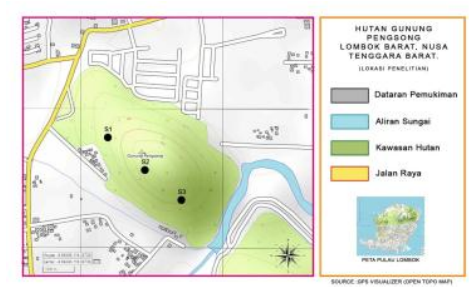

Gambar 1. Titik Pengambilan Sampel Habitat MEP di TWA Gunung Pengsong

Data yang akan diambil meliputi data biotik dan abiotik, jenis tumbuhan, jumlah individu tumbuhan, diameter batang tumbuhan, dan tinggi tumbuhan. Selain itu, diambil pula suhu udara, kelembaban udara, kelembaban tanah, dan $\mathrm{pH}$ tanah. Kemudian dari data yang diperoleh dilakukan analisis frekuensi (F), frekuensi relatif (FR), kerapatan (K), kerapatan relatif (KR), dominansi (D), dominansi relatif (DR), indeks nilai penting (INP), indeks keanekaragaman tumbuhan (H'), dan indeks kemerataan spesies $(\mathrm{E})$.

Teknik analisis data yang digunakan dalam penelitian MEP di TWA Gunung Pengsong sebagai berikut:

1. Analisis Vegetasi 
Parameter analisis vegetasi dihitung dengan menggunakan rumus menurut Hardjosuwono (1994), Cox (1974) yang digunakan oleh Al Idrus (2014) sebagai berikut:

Penentuan Basal Area (BA) dengan rumus:

$$
\begin{aligned}
& \text { 1. } B A=\left(\frac{d}{2}\right)^{2} \times 3,1429 \text { atau } B A=\pi r^{2} \\
& \text { Keterangan: } \\
& \mathrm{BA}=\text { Basal Area } \\
& \pi=3,14 \\
& \mathrm{~d}=\text { diameter batang spesies tumbuhan yang diukur } \\
& \text { setinggi dada (DBH) } \\
& \text { 2. } \text { Kerapatan }=\frac{\text { Jumlah individu suatu spesies }}{\text { Luas area cuplikan }} \\
& \text { 3. Kerapatan Relatif }(K R) \\
& =\frac{\text { Kerapatan suatu spesies }}{\text { Total kerapatan semua spesies }} \times 100 \% \\
& \text { 4. Dominansi }=\frac{\text { Total basal area suatu spesies }}{\text { Luas area cuplikan }} \\
& \text { 5. Dominansi Relatif (DR) } \\
& =\frac{\text { Dominansi suatu spesies }}{\text { Total dominansi seluruh spesies }} \times 100 \% \\
& \text { 6. Frekuensi } \\
& =\frac{\text { Jumlah plot dimana suatu spesies terdapat }}{\text { Total seluruh plot }} \\
& \text { 7.Frekuensi Relatif }(F R)= \\
& \frac{\text { Frekuensi suatu spesies }}{\text { Total frekuensi seluruh spesies }} \times 100 \% \\
& \text { 8. Indeks Nilai Penting }=K R+D R+F R
\end{aligned}
$$

2. Keanekaragaman Tumbuhan (H')

$$
\text { Indeks keanekaragaman }
$$

menggambarkan keadaan populasi organisme secara matematis agar mempermudah dalam menganalisis informasi jumlah individu masing-masing jenis pada suatu komunitas. Untuk itu dilakukan perhitungan dengan menggunakan persamaan dari Shannon-Wiener (Krebs, 1989 dalam Kusumaningsari et al., 2015).

$$
H^{\prime}=-\sum_{i=1}^{s}(p i)(\ln p i)
$$

Keterangan:

$H^{\prime}=$ Indeks Keanekaragaman ShannonWeiner

$p i=$ Perbandingan jumlah individu dengan total individu

$\mathrm{s}=$ jumlah total individu seluruh jenis

3. Kemerataan Tumbuhan

Nilai kemerataan tumbuhan dihitung dengan menggunakan indeks kemerataan spesies (eveness) dengan rumus yang digunakan yaitu:

$H^{\prime}=-\sum_{i=1}^{S}(p i)(\ln p i) \rightarrow E=\frac{H^{\prime}}{\operatorname{Ln} S}$

Keterangan:

$\mathrm{H}^{\prime}=$ Indeks keanekaragaman ShannonWeiner

$p i=$ Perbandingan jumlah individu dengan

total individu

$\mathrm{N}=$ Total jumlah individu semua spesies

$\mathrm{S}=$ Jumlah spesies

$\mathrm{Ln}=$ Logaritma natural

\section{Hasil dan Pembahasan}

Hasil penelitian dari karakteristik habitat Macaca fascicularis terbagi menjadi beberapa bagian utama yakni hasil identifikasi spesies tumbuhan yang digunakan, pengelompokkan spesies tumbuhan ke dalam strata vegetasi dan analisis vegetasi. Rekapitulasi data pada tiap komponen yang diukur disajikan dalam bentuk tabel dan diagram yang meliputi spesies tumbuhan, Indeks Nilai Penting (INP) spesies tumbuhan, keanekaragaman tumbuhan, dan kemerataan tumbuhan. yang digunakan sebagai habitat oleh Macaca fascicularis di TWA Gunung Pengsong.

\section{Kondisi Fisik Lokasi Penelitian}

TWA Gunung Pengsong terletak pada ketinggian 700 mdpl memiliki luas areal kurang lebih 11 ha. Dengan batas wilayah: Sebelah utara: Perkebunan Warga, Sebelah selatan: Rumah Penduduk, Sebelah timur: Area Sawah, Sebelah barat: Perumahan Penduduk Gunung Pengsong. Area hutan tersebut memiliki satu tipe habitat yakni habitat hutan hujan tropis. Suhu udara di TWA Gunung Pengsong berkisar antara $26^{\circ} \mathrm{C}$ sampai dengan $29^{\circ} \mathrm{C}$. Kelembaban udara di TWA Gunung Pengsong berkisar antara $61 \%$ sampai dengan 69\%. Kelembaban tanah di TWA Gunung Pengsong berkisar antara 50\% sampai dengan 60\%. pH tanah di TWA Gunung Pengsong berkisar antara 4,8 sampai dengan 5,6. Hasil pengukuran suhu, kelembaban udara, kelembaban tanah, dan $\mathrm{pH}$ tanah di TWA Gunung Pengsong terdapat dalam tabel 1. 
Tabel 1. Suhu, Kelembaban Udara, Kelembaban Tanah, dan $\mathrm{pH}$ Tanah di Stasiun Penelitian Macaca fascicularis

\begin{tabular}{ccccc}
\hline $\begin{array}{c}\text { Stasiun } \\
\text { Pengam } \\
\text { atan }\end{array}$ & $\begin{array}{c}\text { Suh } \\
\mathrm{u} \\
\text { Uda } \\
\text { ra }\end{array}$ & $\begin{array}{c}\text { Kelemba } \\
\text { ban } \\
\text { Udara } \\
(\%)\end{array}$ & $\begin{array}{c}\text { Kelemba } \\
\text { ban } \\
\text { Tanah } \\
(\%)\end{array}$ & $\begin{array}{c}\mathrm{pH} \\
\text { Tan } \\
\text { ah }\end{array}$ \\
\hline I & 26 & 61 & 50 & 5,6 \\
II & 28 & 65 & 57 & 5,2 \\
III & 29 & 69 & 60 & 4,8 \\
\hline Rata-rata & 27,6 & 65 & 55,67 & 5,2 \\
& 7 & & & \\
\hline
\end{tabular}

Suhu udara rata-rata di TWA Gunung Pengong sebesar $27,67^{\circ} \mathrm{C}$. Hal ini tidak jauh berbeda dengan penelitian Santosa et al. (2018) yang melaporkan bahwa monyet ekor panjang di HPGW (Hutan Pendidikan Gunung Walat) memiliki suhu udara dengan rata-rata $25,43^{\circ} \mathrm{C}$.

Kelembaban udara rata-rata di TWA Gunung Pengsong sebesar $65^{\circ} \mathrm{C}$. Hal ini tidak jauh berbeda dengan Santosa et al. (2018) yang melaporkan bahwa monyet ekor panjang di HPGW (Hutan Pendidikan Gunung Walat) ditemukan pada kelembaban udara dengan ratarata $77 \%$. Hal ini tidak berbeda dengan penelitian Kusmardiastuti (2010) yang menyatakan bahwa monyet ekor panjang di SM Paliyan ditemukan pada kelembaban udara berkisar $60-75 \%$.

Kelembaban tanah rata-rata di TWA Gunung Pengsong sebesar 55,67\%. Hal ini tidak jauh berbeda dengan penelitian Risma et al. (2019) yang menyatakan bahwa kelembaban tanah monyet pada hutan dataran rendah di kawasan Taman Nasional Lore Lindu (TNLL) Sulawesi Tengah sebesar $62,6 \%$.

$\mathrm{pH}$ rata-rata di TWA Gunung Pengsong sebesar 5,2 dan termasuk ke dalam kaegori asam, karena tanahnya berada dalam hutan hujan tropis yang keadaan tanah berada pada daerah basah dan penelitian dilakukan saat musim hujan. Hal ini tidak jauh berbeda dengan penelitian Risma et al., (2019) yang menyatakan bahwa $\mathrm{pH}$ tanah monyet pada hutan dataran rendah di kawasan (TNLL) Sulawesi Tengah sebesar 6,9 dan termasuk ke dalam kategori netral.

\section{Spesies Tumbuhan yang digunakan Macaca fascicularis di TWA Gunung Pengsong}

Frekuensi penggunaan spesies tumbuhan oleh Macaca fascicularis selama pengamatan menunjukkan bahwa spesies tumbuhan yang paling sering digunakan oleh Macaca fascicularis adalah Leucaena glauca (Lamtoro) dengan frekuensi perjumpaan sebanyak 8 kali. Selanjutnya disusul oleh Dalbergia latifolia (Sonokeling) dengan frekuensi sebanyak 7 kali. Lebih lengkapnya disajikan pada Tabel 2.

Tabel 2. Spesies Tumbuhan yang digunakan Macaca fascicularis di TWA Gunung Pengsong

\begin{tabular}{|c|c|c|c|c|}
\hline $\begin{array}{l}\text { Nama } \\
\text { Famili }\end{array}$ & $\begin{array}{c}\text { Spesies } \\
\text { Tumbuha } \\
\text { n }\end{array}$ & $\begin{array}{l}\text { Nama } \\
\text { Lokal }\end{array}$ & $\begin{array}{c}\text { Frekuens } \\
\text { i } \\
\text { Penggun } \\
\text { aan }\end{array}$ & $\begin{array}{c}\text { Pers } \\
\text { enta } \\
\text { se } \\
(\%)\end{array}$ \\
\hline $\begin{array}{l}\text { Fabace } \\
\text { ae }\end{array}$ & $\begin{array}{l}\text { Tamarin } \\
\text { dus } \\
\text { indica }\end{array}$ & Asam & 4 & $\begin{array}{c}13,3 \\
3\end{array}$ \\
\hline $\begin{array}{l}\text { Fabace } \\
\text { ae }\end{array}$ & $\begin{array}{l}\text { Acacia } \\
\text { mangium }\end{array}$ & Akasia & 3 & 10 \\
\hline $\begin{array}{l}\text { Fabace } \\
\text { ae }\end{array}$ & $\begin{array}{l}\text { Leucaen } \\
\text { a glauca }\end{array}$ & Lamtoro & 8 & $\begin{array}{c}26,6 \\
7\end{array}$ \\
\hline $\begin{array}{l}\text { Fabace } \\
\text { ae }\end{array}$ & $\begin{array}{l}\text { Erythrin } \\
a \\
\text { variegata }\end{array}$ & Dadap & 2 & 6,67 \\
\hline $\begin{array}{l}\text { Fabace } \\
\text { ae }\end{array}$ & $\begin{array}{l}\text { Dalbergi } \\
\text { a latifolia }\end{array}$ & $\begin{array}{l}\text { Sonokeli } \\
\text { ng }\end{array}$ & 7 & $\begin{array}{c}23,3 \\
3\end{array}$ \\
\hline $\begin{array}{l}\text { Sapind } \\
\text { aceae }\end{array}$ & $\begin{array}{l}\text { Schleiche } \\
\text { ra oleosa }\end{array}$ & Kesambi & 4 & $\begin{array}{c}13,3 \\
3\end{array}$ \\
\hline $\begin{array}{l}\text { Thymel } \\
\text { aeaceae }\end{array}$ & $\begin{array}{l}\text { Aquilaria } \\
\text { filaria }\end{array}$ & Gaharu & 2 & 6,67 \\
\hline
\end{tabular}

Spesies tumbuhan yang paling sering dijumpai dan ditempati oleh Macaca fascicularis adalah Leucaena glauca (Lamtoro) dengan persentase sebesar 26,67\%. Leucaena glauca (Lamtoro) merupakan spesies tumbuhan dari famili Fabaceae (polong-polongan). Penyebaran Leucaena glauca (Lamtoro) dewasa maupun anakannya di TWA Gunung Pengsong merata, hampir di sepanjang jalur pengamatan tumbuhan ini ditemukan.

Leucaena glauca (Lamtoro) mempunyai peranan yang besar dari spesies tumbuhan lainnya ditinjau dari kerapatan, frekuensi, dan dominansi yang terangkum dalam nilai penting. Hal ini dikarenakan tumbuhan ini adalah spesies tumbuhan yang mudah beradaptasi, tahan terhadap kekeringan, dan tumbuh dengan cepat di berbagai daerah tropis di Asia maupun Afrika. Macaca fascicularis di kawasan TWA Gunung Pengsong memilih tumbuhan ini dikarenakan sebagai pohon pelindung/peneduh saat 
beristirahat dan tidak mudah diterpa saat ada angin kencang. Setiawan et al. (2013) menyatakan bahwa monyet ekor panjang menyukai pohon untuk tidur dan beristirahat yang berkarakteristik tinggi, tidak ditumbuhi liana, dan terlindung dari sinar matahari maupun hujan.

\section{Komposisi Vegetasi}

Penelitian tentang analisis struktur vegetasi tumbuhan pada habitat Macaca fascicularis di TWA Gunung Pengsong di Desa Kuranji, Lombok Barat ditemukan 25 jenis tumbuhan yang tergolong dalam 15 famili. Hasil dari penelitian mengenai komposisi vegetasi terdapat dalam tabel 3.

Tabel 3. Komposisi Vegetasi

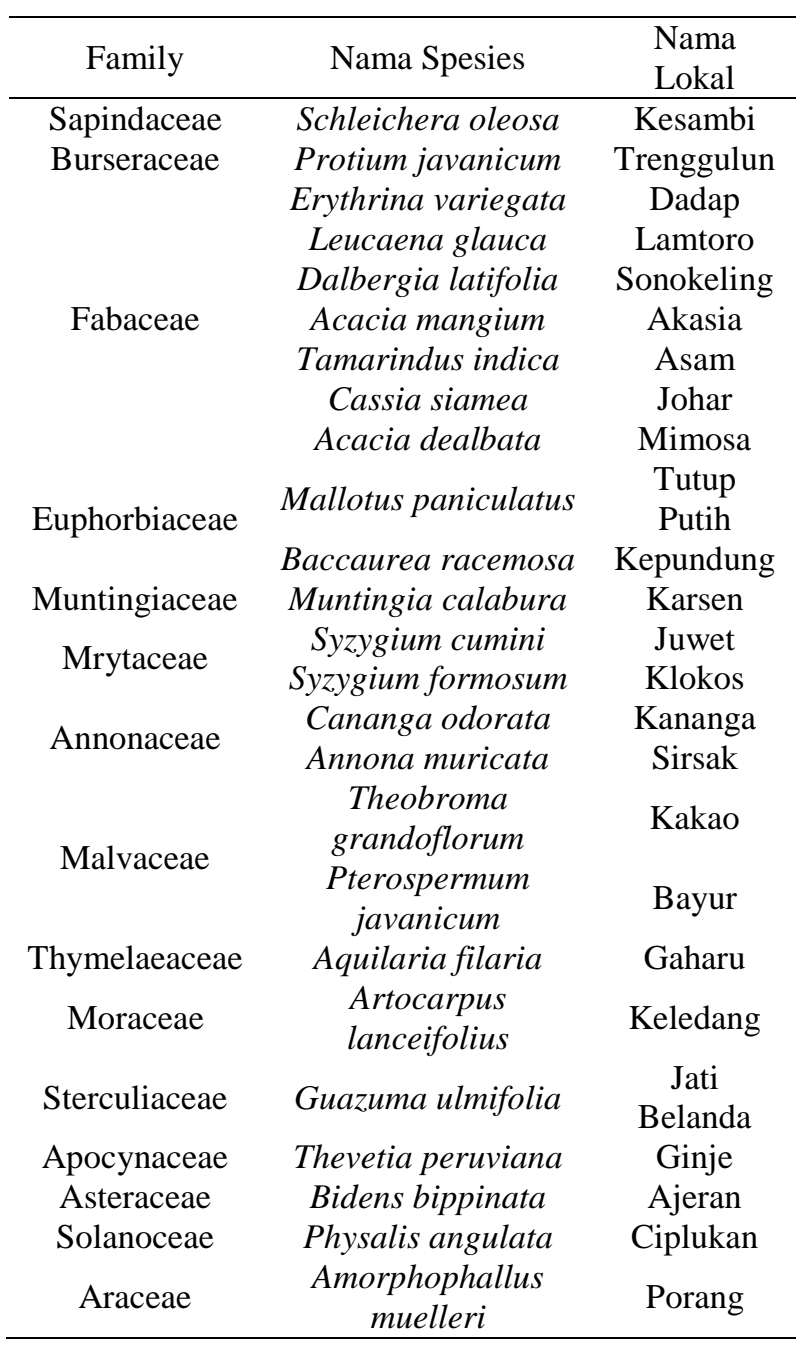

\section{Struktur Vegetasi}

Hasil analisis struktur vegetasi disertai dengan perhitungan beberapa parameter meliputi frekuensi relatif, kerapatan relatif, dominansi relatif, dan indeks nilai penting, yang dibagi menjadi 4 tingkat pertumbuhan yakni pohon, tiang, pancang, dan semai.

\section{Frekuensi Relatif}

\section{Pohon}

Spesies tumbuhan yang memiliki frekuensi relatif tertinggi adalah Leucaena glauca (Lamtoro) sebesar 17,647\%. Spesies tumbuhan-tumbuhan yang memiliki frekuensi relatif terendah meliputi Protium javanicum (Trenggulun), Syzygium cumini (Juwet), Cananga odorata (Kenanga), Theobroma grandoflorum (Kakao), Acacia mangium (Akasia), Artocarpus lanceifolius (Keledang), Pterospermum javanicum (Bayur), dan Tamarindus indica (Asam) sebesar 1,961\%.

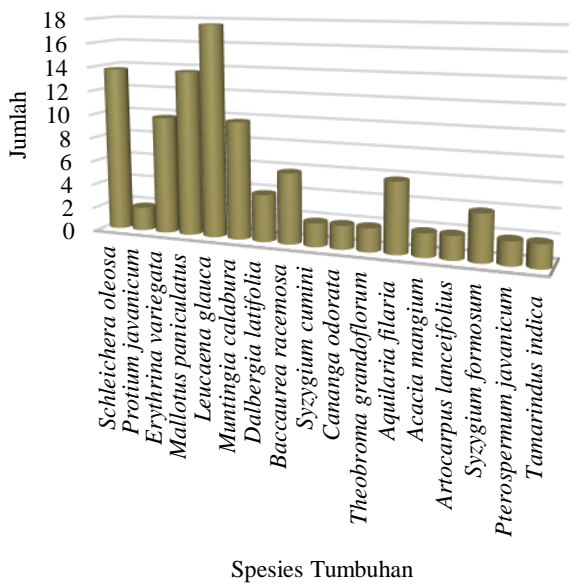

Gambar 2. Frekuensi Relatif Vegetasi Tingkat Pohon

\section{Tiang}

Spesies tumbuhan yang memiliki frekuensi relatif tertinggi adalah Mallotus paniculatus (Tutup Putih) sebesar 27,778\%. Spesies tumbuhan-tumbuhan yang memiliki frekuensi relatif terendah adalah Erythrina variegata (Dadap), Guazuma ulmifolia (Jati Belanda), Thevetia peruviana (Ginje), dan Protium javanicum (Trenggulun) sebesar $5,556 \%$. 


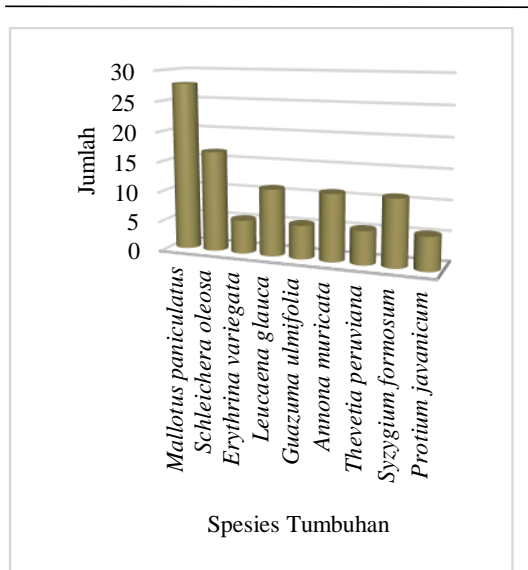

Gambar 3. Frekuensi Relatif Vegetasi Tingkat Tiang

\section{Pancang}

Spesies tumbuhan-tumbuhan yang memiliki frekuensi relatif tertinggi adalah Schleichera oleosa (Kesambi) dan Leucaena glauca (Lamtoro) sebesar 20\%. Spesies-spesies tumbuhan yang memiliki frekuensi relatif terendah adalah Cananga odorata (Kenanga), Cassia siamea (Johar), Theobroma grandoflorum (Kakao), Annona muricata (Sirsak), Erythrina variegata (Dadap), dan Bidens bippinata (Ajeran) sebesar 10\%.

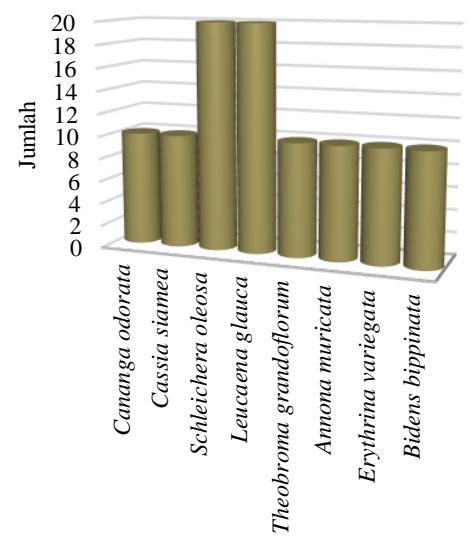

Spesies Tumbuhan

Gambar 4. Frekuensi Relatif Vegetasi Tingkat Pancang

\section{Semai}

Spesies tumbuhan-tumbuhan yang memiliki frekuensi relatif tertinggi adalah Leucaena glauca (Lamtoro) dan Physalis angulata (Ciplukan) sebesar 33,333\%. Spesies tumbuhan-tumbuhan yang memiliki frekuensi relatif terendah adalah Amorphophallus muelleri (Porang) dan Acacia dealbata (Mimosa) sebesar $16,667 \%$.

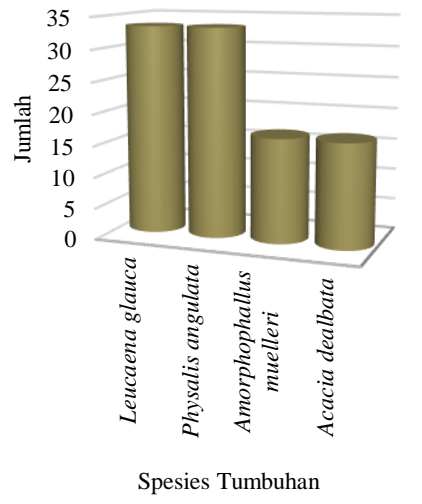

Gambar 5. Frekuensi Relatif Vegetasi Tingkat Semai

Nilai frekuensi relatif tertinggi di TWA Gunung Pengsong adalah spesies tumbuhan Leucaena glauca (Lamtoro) dan Physalis angulata (Ciplukan) masing-masing sebesar 33,333\%. Tumbuhan yang memiliki frekuensi relatif tertinggi terdapat pada tingkat semai, hal tersebut dikarenakan jumlah tumbuhan yang banyak. Menurut Greig-Smith (1983) dalam Martono (2012) nilai frekuensi suatu jenis dipengaruhi secara langsung oleh densitas (kerapatan) dan pola distribusinya. Nilai distribusi hanya dapat memberikan informasi tentang kehadiran tumbuhan tertentu dalam suatu plot dan belum dapat memberikan gambaran tentang jumlah individu pada masing-masing plot.

\section{Kerapatan Relatif}

\section{Pohon}

Spesies tumbuhan yang memiliki kerapatan relatif tertinggi adalah Leucaena glauca (Lamtoro) sebesar 19,126\%. Spesies tumbuhan-tumbuhan yang memiliki nilai kerapatan relatif terendah adalah Cananga odorata (Kenanga), Acacia mangium (Akasia), Pterospermum javanicum (Bayur), dan Tamarindus indica (Asam) sebesar 0,546\%. 


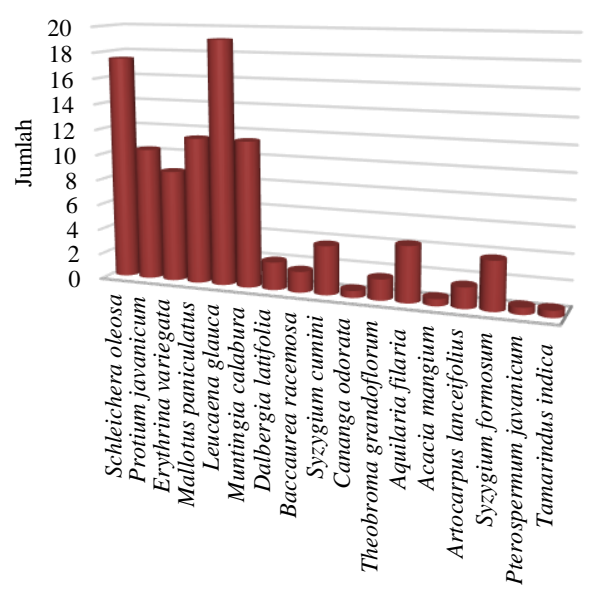

Spesies Tumbuhan

Gambar 6. Kerapatan Relatif Vegetasi Tingkat Pohon

\section{Tiang}

Spesies tumbuhan yang memiliki kerapatan relatif tertinggi adalah Mallotus paniculatus (Tutup Putih) sebesar 45,57\%. Spesies tumbuhan yang memiliki kerapatan relatif terendah adalah Protium javanicum (Trenggulun) sebesar 1,266\%.

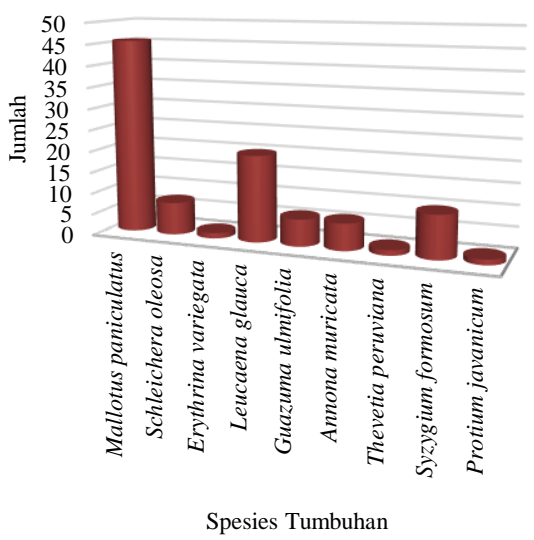

Gambar 7. Kerapatan Relatif Vegetasi Tingkat Tiang

\section{Pancang}

Spesies tumbuhan yang memiliki kerapatan relatif tertinggi adalah Cananga odorata (Kenanga) sebesar 21,053\%. Spesies tumbuhan-tumbuhan yang memiliki kerapatan relatif terendah adalah Annona muricata (Sirsak) dan Erythrina variegata (Dadap) sebesar $1,754 \%$.

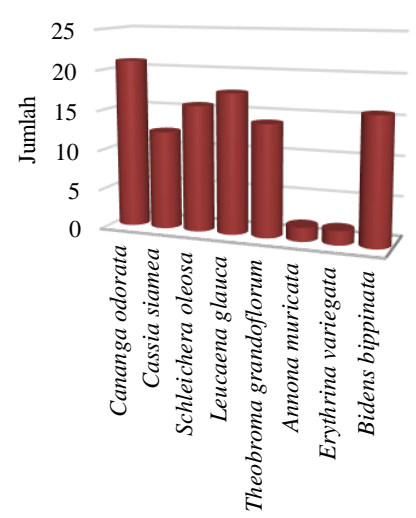

Spesies Tumbuhan

Gambar 8. Kerapatan Relatif Vegetasi Tingkat Pancang

\section{Semai}

Spesies tumbuhan-tumbuhan yang memiliki kerapatan relatif tertinggi adalah Leucaena glauca (Lamtoro) sebesar 40,351\%. Spesies tumbuhan yang memiliki kerapatan relatif terendah adalah Amorphophallus muelleri (Porang) sebesar 5,263\%.

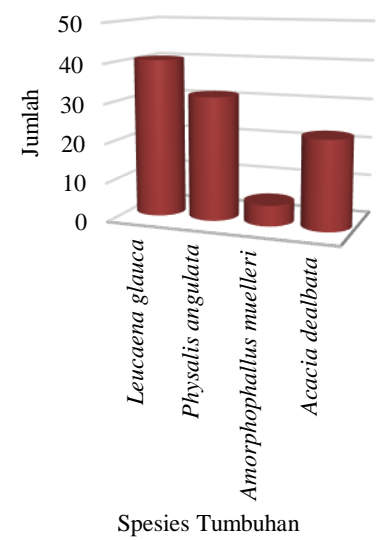

Gambar 9. Kerapatan Relatif Vegetasi Tingkat Semai

Jenis tumbuhan Mallotus paniculatus (Tutup Putih) mempunyai nilai kerapatan relatif tertinggi di TWA Gunung Pengsong sebesar $45,57 \%$. Nilai kerapatan relatif yang besar dari jenis ini, dikarenakan jenis ini merupakan jenis tumbuhan pemenang dalam persaingan dan mempunyai toleransi yang lebar, sehingga persatuan luasnya akan dijumpai individu yang lebih besar. Nilai kerapatan suatu spesies menunjukkan jumlah individu spesies bersangkutan pada satuan luas tertentu, maka nilai kerapatan merupakan gambaran mengenai 
jumlah spesies tersebut pada lokasi penelitian. Menurut Aprijani et al. (2006) dalam Ahmad et al. (2016) mengatakan bahwa nilai kerapatan belum dapat memberikan gambaran tentang bagaimana distribusi dan pola penyebarannya.

\section{Dominansi Relatif}

\section{Pohon}

Spesies tumbuhan yang memiliki dominansi relatif tertinggi adalah $30,559 \%$. Spesies tumbuhan yang memiliki dominansi relatif terendah adalah Dalbergia latifolia (Sonokeling) sebesar 0,059\%.

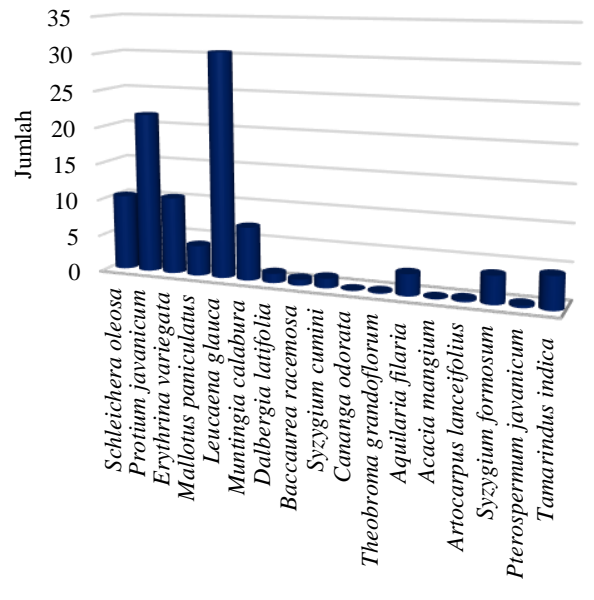

Spesies Tumbuhan

Gambar 10. Dominansi Relatif Vegetasi Tingkat Pohon

\section{Tiang}

Spesies tumbuhan yang memiliki dominansi relatif tertinggi adalah Mallotus paniculatus (Tutup Putih) sebesar 44,938\%. Spesies tumbuhan-tumbuhan yang memiliki dominansi relatif terendah adalah Thevetia peruviana (Ginje) dan Protium javanicum (Trenggulun) sebesar 1,987\%.

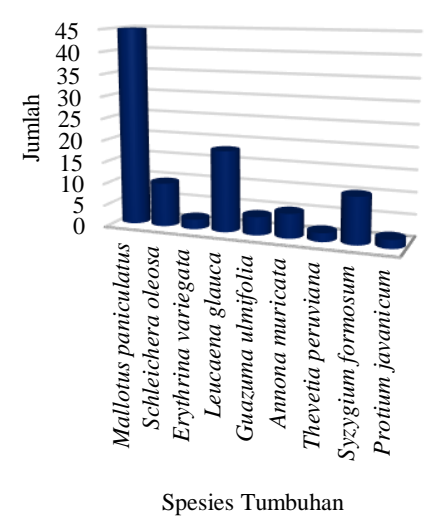

Gambar 11. Dominansi Relatif Vegetasi Tingkat Tiang

\section{Pancang}

Spesies tumbuhan yang memiliki dominansi relatif tertinggi adalah Cananga odorata (Kenanga) sebesar 21,053\%. Spesies tumbuhan-tumbuhan yang memiliki dominansi relatif terendah adalah Annona muricata (Sirsak) dan Erythrina variegata (Dadap) sebesar $1,754 \%$.

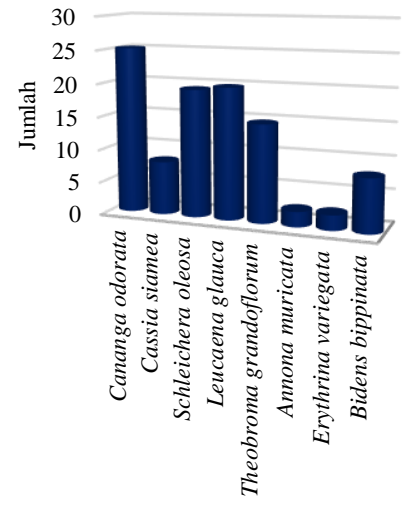

Spesies Tumbuhan

Gambar 12. Dominansi Relatif Vegetasi Tingkat Pancang

\section{Semai}

Spesies tumbuhan yang memiliki kerapatan relatif tertinggi adalah Leucaena glauca (Lamtoro) sebesar 38,701\%. Spesies tumbuhan yang memiliki kerapatan relatif terendah adalah Acacia dealbata (Mimosa) sebesar $13,126 \%$. 


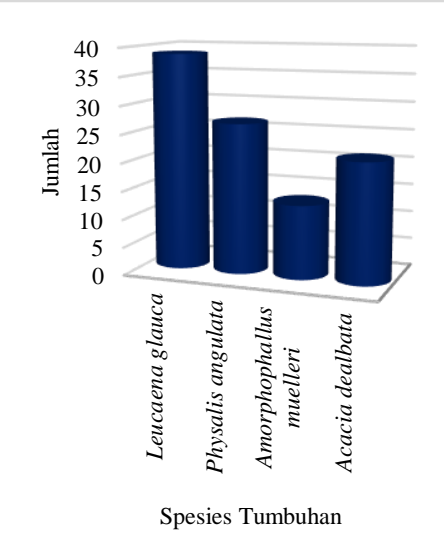

Gambar 13. Dominansi Relatif Vegetasi Tingkat Semai

Struktur vegetasi di TWA Gunung Pengsong terlihat bahwa jenis tumbuhan Cananga odorata (Kenanga) mempunyai nilai dominansi relatif yang tinggi, sebesar 56,224\%. Hal ini diduga karena jenis-jenis tersebut mampu bersaing dengan jenis-jenis tumbuhan lain dalam mendapatkan sinar matahari dan unsur hara dalam tanah. Menurut Ahmad et al. (2016) menyatakan bahwa kondisi ini menyebabkan suplai makanan yang lebih besar dan penyebaran yang lebih luas sehingga jenis-jenis tersebut akan memperoleh sumber-sumber keperluan hidupnya (air, cahaya dan unsur hara) secara lebih baik dari pesaingnya.

\section{Indeks Nilai Penting}

\section{Pohon}

Spesies tumbuhan yang memiliki nilai penting tertinggi adalah Leucaena glauca (Lamtoro) sebesar 67,331\%. Spesies tumbuhan yang memiliki nilai penting terendah adalah Cananga odorata (Kenanga) sebesar 2,566\%.

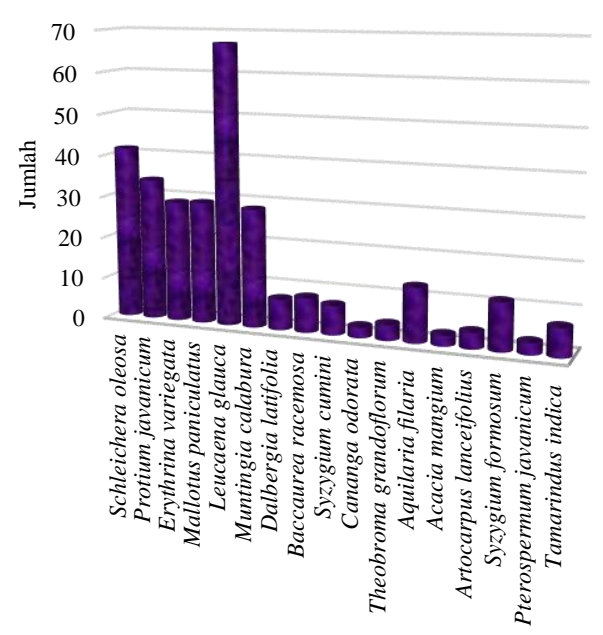

Spesies Tumbuhan

Gambar 14. INP Vegetasi Tingkat Pohon

Tiang

Spesies tumbuhan yang memiliki nilai penting tertinggi adalah Mallotus paniculatus (Tutup Putih) sebesar 118,286\%. Spesies-spesies tumbuhan yang memiliki nilai penting terendah adalah Thevetia peruviana (Ginje), dan Protium javanicum (Trenggulun) masing-masing sebesar $8,808 \%$.

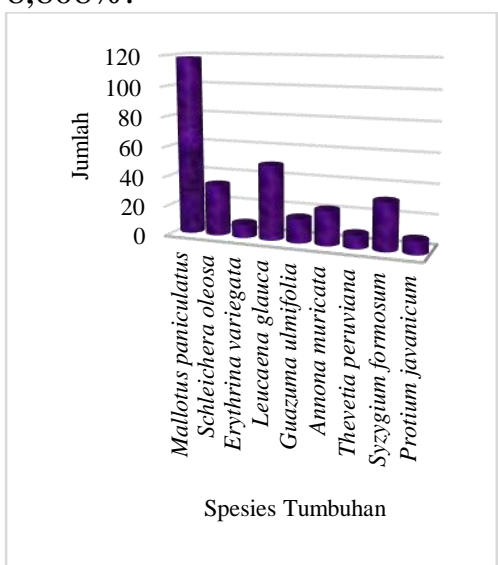

Gambar 15. INP Vegetasi Tingkat Tiang

\section{Pancang}

Spesies-spesies tumbuhan yang memiliki nilai penting tertinggi adalah Leucaena glauca (Lamtoro) sebesar 57,421\%. Spesiesspesies tumbuhan yang memiliki nilai penting terendah adalah Annona muricata (Sirsak) dan Erythrina variegata (Dadap) masing-masing sebesar $14,059 \%$. 


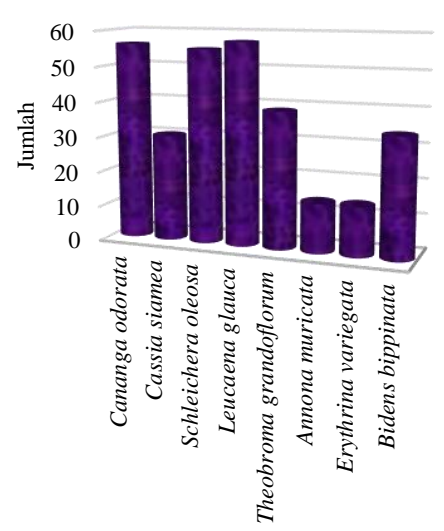

Spesies Tumbuhan

Gambar 16. INP Vegetasi Tingkat Pancang

\section{Semai}

Spesies tumbuhan yang memiliki nilai penting tertinggi adalah Leucaena glauca (Lamtoro) sebesar 112,385\%. Spesies tumbuhan yang memiliki nilai penting terendah adalah Amorphophallus muelleri (Porang) sebesar $35,056 \%$.

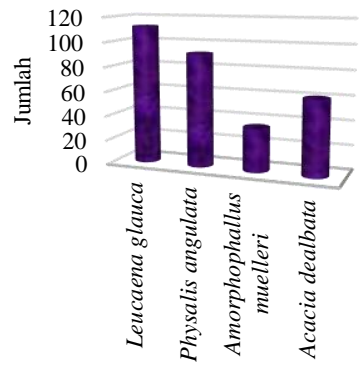

Spesies Tumbuhan

Gambar 17. INP Vegetasi Tingkat Semai

Struktur vegetasi terlihat jenis tumbuhan Mallotus paniculatus (Tutup Putih) yang memiliki INP paling besar dan tertinggi, dengan nilai sebesar $118,286 \%$, berarti jenis tersebut mempunyai peranan yang paling besar bila dibandingkan dengan jenis tumbuhan yang lainnya. Menurut Martono (2012), apabila nilai INP suatu jenis vegetasi bernilai tinggi, maka jenis tumbuhan tersebut sangat mempengaruhi kestabilan ekosistem tersebut. Sehingga tumbuhan Mallotus paniculatus (Tutup Putih), sangat mempengaruhi kestabilan ekosistem di TWA Gunung Pengsong.

\section{Keanekaragaman Tumbuhan}

Nilai Indeks Shannon-Weiner dari semua spesies tumbuhan di TWA Gunung Pengsong terdapat dalam tabel 4.

Tabel 4. Keanekaragaman Tumbuhan

\begin{tabular}{|c|c|c|c|c|}
\hline $\begin{array}{l}\text { Nama } \\
\text { Lokal } \\
\end{array}$ & Nama Spesies & $\begin{array}{l}\text { Jumlah } \\
\text { Spesies } \\
\end{array}$ & $\begin{array}{l}\text { pi Ln } \\
\text { pi }\end{array}$ & $\mathrm{H}^{\prime}$ \\
\hline Kesambi & $\begin{array}{l}\text { Schleichera } \\
\text { oleosa }\end{array}$ & 47 & $\begin{array}{c}0,259 \\
9\end{array}$ & \\
\hline Trenggulun & $\begin{array}{l}\text { Protium } \\
\text { javanicum }\end{array}$ & 20 & $\begin{array}{c}0,156 \\
1\end{array}$ & \\
\hline Dadap & $\begin{array}{l}\text { Erythrina } \\
\text { variegata }\end{array}$ & 18 & $\begin{array}{c}0,145 \\
5\end{array}$ & \\
\hline Tutup Putih & $\begin{array}{l}\text { Mallotus } \\
\text { paniculatus }\end{array}$ & 57 & $\begin{array}{c}0,286 \\
0\end{array}$ & \\
\hline Lamtoro & Leucaena glauca & 84 & $\begin{array}{c}0,334 \\
8\end{array}$ & \\
\hline Karsen & $\begin{array}{l}\text { Muntingia } \\
\text { calabura }\end{array}$ & 21 & $\begin{array}{c}0,161 \\
1\end{array}$ & \\
\hline Sonokeling & $\begin{array}{l}\text { Dalbergia } \\
\text { latifolia }\end{array}$ & 4 & $\begin{array}{c}0,048 \\
3\end{array}$ & \\
\hline Kepundung & $\begin{array}{l}\text { Baccaurea } \\
\text { racemosa }\end{array}$ & 3 & $\begin{array}{c}0,038 \\
5\end{array}$ & \\
\hline Juwet & Syzygium cumini & 7 & $\begin{array}{c}0,074 \\
2\end{array}$ & \\
\hline Kenanga & Cananga odorata & 13 & $\begin{array}{c}0,116 \\
3\end{array}$ & 2,62 \\
\hline Kakao & $\begin{array}{l}\text { Theobroma } \\
\text { grandoflorum }\end{array}$ & 11 & $\begin{array}{c}0,103 \\
3\end{array}$ & 3 \\
\hline Gaharu & Aquilaria filaria & 8 & $\begin{array}{c}0,081 \\
9\end{array}$ & \\
\hline Akasia & Acacia mangium & 1 & $\begin{array}{c}0,015 \\
8\end{array}$ & \\
\hline Keledang & $\begin{array}{l}\text { Artocarpus } \\
\text { lanceifolius }\end{array}$ & 3 & $\begin{array}{c}0,038 \\
5\end{array}$ & \\
\hline Klokos & $\begin{array}{l}\text { Syzygium } \\
\text { formosum }\end{array}$ & 15 & $\begin{array}{c}0,128 \\
5\end{array}$ & \\
\hline Bayur & $\begin{array}{l}\text { Pterospermum } \\
\text { javanicum }\end{array}$ & 1 & $\begin{array}{c}0,015 \\
8\end{array}$ & \\
\hline Asam & $\begin{array}{l}\text { Tamarindus } \\
\text { indica }\end{array}$ & 1 & $\begin{array}{c}0,015 \\
8\end{array}$ & \\
\hline $\begin{array}{l}\text { Jati } \\
\text { Belanda }\end{array}$ & $\begin{array}{l}\text { Guazuma } \\
\text { ulmifolia }\end{array}$ & 5 & $\begin{array}{c}0,057 \\
4\end{array}$ & \\
\hline Sirsak & Annona muricata & 6 & $\begin{array}{c}0,066 \\
0\end{array}$ & \\
\hline Ginje & $\begin{array}{l}\text { Thevetia } \\
\text { peruviana }\end{array}$ & 1 & $\begin{array}{c}0,015 \\
8\end{array}$ & \\
\hline Johar & Cassia siamea & 7 & $\begin{array}{c}0,074 \\
2\end{array}$ & \\
\hline Ajeran & Bidens bippinata & 9 & $\begin{array}{c}0,089 \\
3\end{array}$ & \\
\hline Ciplukan & Physalis angulata & 18 & $\begin{array}{c}0,145 \\
5\end{array}$ & \\
\hline Porang & $\begin{array}{l}\text { Amorphophallus } \\
\text { muelleri }\end{array}$ & 3 & $\begin{array}{c}0,038 \\
5\end{array}$ & \\
\hline Mimosa & Acacia dealbata & 13 & $\begin{array}{c}0,116 \\
3 \\
\end{array}$ & \\
\hline \multicolumn{2}{|c|}{ Jumlah } & 376 & $\begin{array}{c}2,623 \\
5 \\
\end{array}$ & \\
\hline
\end{tabular}

Menurut Barbour et al., (1987) dalam Setiadi (2004) nilai indeks keanekaragaman dapat berkisar antara 0-7, dengan kriteria: 0-2 (rendah), 2-3 (sedang), dan > 3-7 (tinggi). Berdasarkan hasil perhitungan diperoleh nilai dari indeks keanekaragaman tumbuhan di 
kawasan TWA Gunung Pengsong sebesar 2,623. Sehingga keanekaragaman tumbuhan di TWA Gunung Pengsong tergolong sedang. Hasil penelitian ini hampir serupa dengan penelitian Hidayat (2017) yang mengatakan bahwa dari hasil analisis vegetasi diperoleh indeks keanekaragaman tumbuhan di daerah geothermal Ies Suum Kecamatan Mesjid Raya Kabupaten Aceh Besar adalah 3,508, hasil yang didapat menunjukkan tingkat keanekaragaman tinggi.

\section{Kemerataan Tumbuhan}

Nilai kemerataan tumbuhan dihitung dengan menggunakan indeks kemerataan spesies (eveness). Nilai indeks kemerataan spesies (eveness) berkisar 0-1, jika nilainya 0 menunjukkan tingkat kemerataan spesies tumbuhan pada komunitas tersebut sangat tidak merata, sedangkan jika nilainya mendekati 1 maka hampir seluruh spesies yang ada mempunyai kelimpahan yang sama. Hasil perhitungan kemerataan tumbuhan di TWA Gunung Pengsong terdapat dalam tabel 5.

Tabel 5. Kemerataan Tumbuhan

\begin{tabular}{cc}
\hline $\boldsymbol{H}^{\prime}$ & 2,623 \\
\hline $\boldsymbol{L n} \boldsymbol{S}(\mathbf{2 5})$ & 3,218 \\
\hline $\mathrm{E}$ & 0,815 \\
\hline
\end{tabular}

Nilai dari kemerataan tumbuhan di kawasan TWA Gunung Pengsong sebesar 0,815. Berdasarkan Magurran (1988) dalam Hilwan et al., (2013), besaran nilai $\mathrm{E}<0,3$ menunjukkan kemerataan jenis rendah, $\mathrm{E}=0,3-0,6$ menunjukkan kemerataan jenis tergolong sedang, dan $\mathrm{E}>$ 0,6 menunjukkan kemerataan jenis tergolong tinggi. Jadi, kemerataan tumbuhan di TWA Gunung Pengsong tergolong tinggi. Hasil penelitian ini hampir serupa dengan penelitian Dhaja et al., (2019) yang mengatakan bahwa dari hasil analisa vegetasi diperoleh indeks kemerataan tumbuhan di kawasan TRGMT (Taman Rekreasi Gua Monyet Tenau) adalah 0,79, dengan demikian dapat dikatakan bahwa kemerataan tumbuhan di kawasan TRGMT tergolong tinggi.

\section{Kesimpulan}

Dari hasil penelitian karakteristik habitat monyet ekor panjang (Macaca fascicularis) di
TWA Gunung Pengsong, dapat disimpulkan bahwa habitat monyet ekor panjang (Macaca fascicularis) di TWA Gunung Pengsong kawasan hutan dataran rendah, ditemukan 25 jenis tumbuhan yang tergolong ke dalam 15 famili. Spesies tumbuhan yang memiliki nilai INP paling besar dan tertinggi adalah Mallotus paniculatus (Tutup Putih). Keanekaragaman tumbuhan di kawasan TWA Gunung Pengsong tergolong sedang dan kemerataan tumbuhan di kawasan TWA Gunung Pengsong tergolong tinggi.

\section{Ucapan Terima Kasih}

Penelitian ini dapat dilaksanakan dengan baik berkat bantuan dari berbagai pihak, oleh sebab itu peneliti mengucapkan terima kasih kepada pengelola TWA Gunung Pengsong, dan teman-teman yang telah membantu.

\section{Referensi}

Afitah, I. (2016). Persepsi Masyarakat Tentang Keberadaan Monyet Ekor Panjang (Macaca Fascicularis) di Desa Tumbang Nusa Kabupaten Pulang Pisau Kalimantan Tengah. Jurnal Anterior, 16(1), 67-76.

Ahmad, H., Chumidach R., \& Sarmi A. (2016). Analisis Struktur Vegetasi pada Habitat Kupu-Kupu (Papilio ulysses) di Pulau Kasiruta. Jurnal Biology, 4(2), 517-527.

Al Idrus, A. (2014). Mangrove Gili Sulat Lombok Timur. Lombok Barat: Arga Puji Press.

Alikodra, H. S. (2002). Pengelolaan Satwa Liar Jilid I. Bogor: Yayasan Penerbitan Fakultas Kehutanan Institut Pertanian Bogor.

Anita, Ikhmatal, M., Lia, S., \& Hendriansyah. (2015). Prosiding Seminar Nasional Biotik. Aceh: Mei 2015. Hal: 115-118.

CITES (2014). Macaca fascicularis (Raffles, 1821): Cambodia, India, Indonesia, Lao People's Democratic Republic, Mauritius, Palau, Philippines, Viet Nam. United Kingdom: United Nations Environment 
Programme World Conservation Monitoring Centre.

Departemen Kehutanan (1989). Statistik Kehutanan Indonesia 1988. Jakarta: Departemen Kehutanan.

Dhaja, C. A., Yohanes, T. R. M. R. S., \& Gerson, N. (2019). Kondisi Populasi dan Habitat Monyet Ekor Panjang (Macaca fascicularis). Jurnal Veteriner Nusantara, 2(1), 46-54.

Gumert, M. (2011). The Common Monkey of Southeast Asia: Long-tailed Macaque Populations, Ethnophoresy, and Their Occurrence in Human Environments. Cambridge, UK: Cambridge University Press.

Hidayat, M. (2017). Analisis Vegetasi dan Keanekaragaman Tumbuhan di Kawasan Manifestasi Geotermal Ie Suum Kecamatan Mesjid Raya Kabupaten Aceh Besar. Jurnal Biotik, 5(2), 114-124.

Hilwan, I., Mulyana, D., \& Pananjung, W. G. (2012). Keanekaraaman Jenis Tumbuhan Bawah pada Tegakan Sengon Buto (Enterolobium cyclocarpum Griseb.) dan Trembesi (Samanea saman Merr.) di Lahan Pasca Tambang Batubara PT Kitadin, Embalut, Kutai Kartanagara, Kalimantan Timur. Jurnal Silvikultur Tropika, 4(1), 6-10.

Jawadi, F., \& Raden, R. N. D. R. (2018). Studi Perilaku Individu Jantan Alfa Monyet Ekor Panjang (Macaca fascicularis) di TWA Gunung Pengsong Kabupaten Lombok Barat. Jurnal Silva Samalas, 2(1), $39-45$.

Kusmardiastuti (2010). Penentuan Kuota Panen Monyet Ekor Panjang (Macaca fascicularis) Berdasarkan Parameter Demografi (Tesis, Program Pasca Sarjana, Institut Pertanian Bogor).

Kusumaningsari, S. D., Boedi H., \& Ruswahyuni. (2015). Kelimpahan Hewan Makrobentos pada Dua Umur Tanam
Rhizophora sp. di Kelurahan Mangunharjo Semarang. Diponegoro Journal of Maquares, 4(2), 58-64.

Martono, D. S. (2012). Analisis Vegetasi dan Asosiasi antara Jenis-Jenis Pohon Utama Penyusun Hutan Tropis Dataran Rendah di Taman Nasional Gunung Rinjani Nusa Tenggara Barat. Jurnal Agri-tek, 13(2), 18-27.

Risma, Wahyu, H., \& Ramadanil. (2019). Kajian Autekologi Harao Areca vestiaria Giseke pada Hutan Dataran Rendah di Kawasan Taman Nasional Lore Lindu (TNLL) Sulawesi Tengah. Jurnal Biocelebes, 13(1), 87-97.

Santosa, Y., Andoko H., \& Abdul H. M. (2018). Studi Populasi dan Pola Penggunaan Ruang Monyet Ekor Panjang (Macaca Fascicularis) di Hutan Pendidikan Gunung Walat. Jurnal Media Konservasi, 18(1), 40-46.

Sari, P. D., Suwarno, Alanindra, S., \& Marjono. (2014). Studi Perilaku Monyet Ekor Panjang (Macaca fascicularis) di Taman Wisata Alam Grojogan Sewu Tawangmangu Karang Anyar. Surakarta: Prodi Pendidikan Biologi FKIP Universitas Sebelas Maret.

Setiadi, D. (2004). Keanekaragaman Spesies Tingkat Pohon di Taman Wisata Alam Ruteng Nusa Tenggara Timur. Jurnal Biodiversitas, 6(2), 118-122.

Setiawan, Aji, M. Kanedi, Elly L. Rustiati, \& Ronald H. P. Panjaitan. (2013). Karakteristik Pohon untuk Tidur Monyet Ekor Panjang (Macaca Fascicularis) di Kawasan Youth Camp Taman Hutan Raya Wan Abdul Rachman Lampung. Jurnal Ilmiah: Biologi Eksperimen dan Keanekaragaman Hayati, 1(1), 40-43.

Soehartono, T, \& Mardiastuti A. (2003). Pelaksanaan Konvensi CITES di Indonesia. Jakarta: JICA. 
Supriatna, J., \& Rizki, R. (2016). Pariwisata Primata Indonesia. Jakarta: Yayasan Pustaka Obor Indonesia.

Yamin, M., D. Setiadi, \& Khairuddin (2021). Diet and Behavior of Macaca fascicularis for Ecotourism Contributing on Pengsong Area. Jurnal Biologi Tropis, 21(1), 179190. 